Volume 1 Nomor 12020

http://journal.febubhara-sby.org/bharanomic ISSN: $2774-7190$

\title{
DAMPAK PENGEMBANGAN DESA WISATA TERHADAP PENDAPATAN MASYARAKAT DESA WISATA (Studi Pada Desa Pujon Kidul Kecamatan Pujon Kabupaten Malang)
}

\author{
* Renaldo Silooy, Haryono, Nurul Imamah \\ Universitas Bhayangkara Surabaya, Indonesia
}

DOI: 10.46821/bharanomicss.v1i1.15

\begin{abstract}
Abstrak
Penelitian ini di latar belakangi oleh pengamatan penulis mengenai dampak pengembangan desa wsisata terhadap pendapatan masyarakat Desa Pujonkidul kecamatan Pujon kabupaten Malang dengan segala upaya yang ada. Penulis mengambil lokasi di Desa Pujonkidul karena pada lokasi tersebut terdapat pengembangan desa wisata. Metode penelitian menggunakan kualitatif deskriptif teknik pengumpulan data yang digunakan dalam penelitian ini melalui tiga tahap yaitu observasi, wawancara mendalam, dokumentasi. Pengujian data menggunakan teknik triangulasi. Penelitian ini bertujuan untuk mengkaji dampak ekonomi desa Pujonkidul terhadap pendapatan masyarakat sekitar sebelum dan setelah dicanangkan sebagai desa wisata, mengkaji dampak pengembangan desa Pujonkidul terhadap masyarakat sekitar sebelum dan setelah di canangkan sebagai desa wisata. Dari penelitian ini ditemukan bahwa kesimpulan Setelah adanya pengembangan desa wisata di desa Pujonkidul mampu membuka lapangan pekerjaan untuk meningkatkan pendapatan melalui usaha dagang untuk memenuhi kebutuhan wisatawan dan berperan dalam menekan angka pengangguran masyarakat desa. Pengembangan desa wisata juga berdampak pada bidang pertanian dimana para petani mampu membudidayakan lahan pertanian sebagai obyek wisata sehingga menambah pendapatan petani selain dari hasil pertaniannya. Dari dikembangkannya desa Pujonkidul sebagai desa wisata masyarakat desa lebih inovatif dalam mengelola hasil pertanian maupun peternakan menjadi olahan yang memiliki nilai ekonomi yang tinggi Adapun upaya emanfaatan lahan kering guna menambah pembangunan fasilitas umum dan objek wisata seperti penginapan, café sawah, toko oleh-oleh dan taman bermain. Meningkatkan SDM baik kualitas maupun kuantitas melalui pelatihan-pelatihan yang diadakan oleh lembaga terkait untuk menambah pengetahuan dan mendorong masyarakat untuk bisa lebih berfikir inovatif dalam mengembangkan pariwisata di Desa Pujonkidul.. Memberikan penyuluhan bagi masyarakat untuk menciptakan lingkungan yang bersih, sehat dan nyaman sehingga dapat menarik pengunjung wisata.
\end{abstract}

Kata kunci: Pengembangan, Desa Wisata, Pendapatan

\begin{abstract}
:
This research is motivated by the authors' observations on the impact of the development of a tourism village on community income in Pujonkidul Village, Pujon Sub-district, Malang Regency with all the efforts available. The author takes the location in the village of Pujonkidul because at that location there is the development of a tourist village. The research method uses descriptive qualitative data collection techniques used in this study through three stages, namely observation, in-depth interviews, documentation. Testing data using triangulation techniques. This study aims to examine the economic impact of the Pujonkidul village on the income of the surrounding community before and after it was launched as a tourism village, assessing the impact of the development of the Pujonkidul village on the surrounding community before and after it was proposed as a tourist village. From this study it was found that the conclusion After the development of a tourist village in the village of Pujonkidul able to open jobs to increase income through commercial ventures to meet the needs of tourists and play a role in reducing unemployment rates in rural communities. The development of the tourism village also has an impact on agriculture where farmers are able to cultivate agricultural land as a tourist attraction so as to increase farmers' income apart from their agricultural produce. From the development of the village of Pujonkidul as a tourist village, the village community is more innovative in managing agricultural and livestock products to be processed that has high economic value. played. Improve human resources both in quality and quantity through trainings held by related institutions to increase knowledge and encourage the community to be more innovative in thinking about developing tourism in Pujonkidul Village. Providing counseling for the community to create a clean, healthy and comfortable environment so that it can attract tourist visitors.
\end{abstract}

Keywords: Development, Tourist Village, Income

*Corresponding Author:

Hal: $38-42$

Email: aldo.silooy16@gmail.com 


\section{PENDAHULUAN}

Perkembangan kepariwisataan juga menghampiri desa. Hampir setiap desa di Indonesia memiliki potensi pariwisata yang bisa dikembangkan mulai dari kebudayaannya sampai wisata alam yang bisa dijadikan sebuah konsep bisnis yang menjanjikan. Saat ini wisatawan lebih memilih wisata yang bernuansa alam pedesaan yang masih alami dan asri. Dengan melakukan perjalanan wisata ke desa, wisatawan dapat berinteraksi langsung dengan masyarakat desa dan dapat melihat langsung aktivitas sosial budaya masyarakat lokal menurut (Ridwan, 2012)

Pengembagan kepariwisataan dapat membawa banyak manfaat dan keuntungan. Pembangunan kepariwisataan diarahkan pada peningkatan pariwisata menjadi sector andalan yang mampu menyaingi kegiatan ekonomi lainnya, termasuk kegiatan sektor lain yang terkait. Pengembangan di desa wisata dapat mempengaruhi pendapatan penduduk Desa Pujon Kidul khususnya yang terlihat di sektor pariwisata. Dengan meningkatnya pendapatan penduduk maka akan berpengaruh terhadap kondisi ekonomi masyarakat Pujon Kidul.

Pengembangan adalah suatu proses atau cara menjadikan sesuatu menjadi maju, baik, sempurna dan berguna. Maka pengembangan dalam hal ini dapat diartikan membuat menjadi ada hari yang belum ada dari yang sudah ada menjadi lebih baik dan dari sudah baik menjadi lebih baik demikian seterusnya (Purwadarminta,2016).

\section{TINJAUAN PUSTAKA}

\section{Pariwisata}

Pariwisata adalah perjalanan dari satu tempat ke tempat lain bersifat sementara, dilakukan perorangan atau kelompok, sebagai usaha mencari keseimbangan atau keserasian dan kebahagiaan dengan lingkungan dalam dimensi sosial budaya, alam dan ilmu (Kodhyat dalam Kurniansah, 2014).

\section{Dampak}

Dampak secara sederhana bisa diartikan sebagai pengaruh atau akibat. Dalam setiap keputusan yang diambil oleh seseorang atasan biasanya mempunyai dampak tersendiri, baik itu dampak positif maupun negatif. Dampak juga bisa merupakan proses lanjutan dari sebuah pelaksanaan pengawasan internal. Seseorang pemimpin yang handal sudah selayaknya bisa memprediksi jenis dampak yang akan terjadi atas sebuah keputusan yang akan diambil (KBBI Online, 2016).

\section{Desa Wisata}

Desa Wisata adalah suatu bentuk intergrasi antara atraksi, akomodasi dan fasilitas pendukung yang disajikan dalam suatu struktur kehidupan masyarakat yang menyatu dengan tata cara dan tradisi yang berlaku. Desa wisata didefinisikan sebagai sebagian atau kesuluruhan wilayah desa yang dimiliki potensi, produk dan aktivitas wisata yang dapat dimanfaatkan untuk pengembangan pariwisata dan dikelola oleh kelompok masyarakat di desa secara berkelanjutan (Ida Bagus Suryawan, 2015:9). 


\section{Pengembangan}

Pengembangan adalah upaya pendidikan baik formal maupun non formal yang dilaksanakan secara sadar, berencana, terarah, teratur dan bertanggung jawab dalam rangka memperkenalkan, menumbuhkan, membimbing, mengembangkan suatu dasar kepribadian yang seimbang, utuh, selaras, pengetahuan, keterampilan sesuai dengan bakat, keinginan serta kemampuan sebagai bekal atas prakarsa sendiri untuk menambah, meningkatkan, mengembangkan diri ke arah tercapainya martabat, mutu dan kemampuan manusiawi yang optimal dan pribadi mandiri (Iskandar Wiryokusumo dalam Afrilianasari, 2014).

\section{Pendapatan}

Pendapatan dapat diartikan sebagai jumlah keseluruhan uang yang diterima oleh seseorang atau rumah tangga selama jangka waktu tertentu dimana pendapatan terdiri dari upah atau penerimaan tenaga kerja, Pendapatan dari kekayaan seperti sewa, bunga atau dividen serta pembayaran transfer atau penerimaan dari pemerintah seperti tunjangan sosial atau asuransi pengangguran (Paul A Samuel, Wilian Dnordhus, 1992;258 dalam istikomah, 2018)

\section{METODE PENELITIAN}

a) Desa Pujon Kidul dan Selama 5 Bulan (Februari - Juni)

b) Pendekatan Penelitian KualitatiF

c) Metode Pengumpulan Data Triangulasi Gabungan, Observasi, Wawancara Mendalam dan Dokumentasi.

d) Analisis Data Pengumpulan Data, Reduksi Data, Penyajian Data, Penarikan Kesimpulan.

\section{HASIL DAN PEMBAHASAN}

Dampak Pengembangan Desa Wisata Pujon Kidul Terhadap Pendapatan Penduduk Desa Wisata Pujon Kidul

Dampak dari pengembangan desa Wisata Pujon Kidul membuktikan bahwa ada pengaruh terhadap pendapatan warga desa Pujon Kidul. adanya terjadi peningkatan penghasilan dari sebelum dan setelah dikembangkan objek wisata peluang usaha dan keja tersebut lahir karena adanya permintaan wisatawan. Dengan demikiran, kedatangan wisatawan ke suatu daerah akan membuka peluang bagi masyarakat tersebut untuk menjadi penyedia kebutuhan dan jasa wisata. Peluang usaha tersebut akan memberikan kesempatan kepada masyarakat lokal untuk bekerja dan sekaligus dapat menambah pendapatan untuk menunjang kehidupan rumah tanggganya. Dari hasil wawancara dengan beberapa perangkat Desa, mayoritas menyatakan bahwa pendapatan dan kondisi masyarakat sebelum dan setelah desa Pujon Kidul dicanangkan sebagai desa wisata mengalami perubahan. Untuk pendapatan masyarakat juga mengalami peningkatan karena adanya peluang usaha baru yang dapat dibuka guna memfasilitasi Pengembangan Desa Wisata. Seperti pada sektor pertanian, peternakan yang lebih inovatif dalam mengelolah hasil tani dan ternak guna menambah nilai ekonominya. Sedangkan untuk kondisi masyarakat setelah Desa Pujon Kidul di kembangkan sebagai Desa wisata yaitu mengalami keterbukaan 
Bharanomics

Vol. 1 No. 12020

Renaldo Silooy dkk, Dampak Pengembangan Desa Wisata

terhadap teknologi serta kemudahan akses dalam pelayanan internet dan perbankan. Dari hasil observasi dan wawancara dengan masyarakat sekitar, mayoritas masyarakat merasakan merasakan adanya dampak sesudah 62 dicanangkannya desa wisata, dampak yang dirasakan masyarakat salah satunya ialah membuka lapangan pekerjaan bagi masyarakat sekitar dengan adanya lapangan pekerjaan menambah pendapatan masyarakat dan ada perubahan mata pencaharian masyarakat yang membuat adanya peningkatan pendapatan dan juga dampak adanya desa wisata dapat membuka peluang usaha bagi masyarakat sekitar seperti oleh-oleh olahan susu. Pendapatan sebelum dicanangkannya desa wisata masyarakat hanya cukup untuk memenuhi kebutuhan sehari-hari.

Dilihat dari hasil observasi dan wawancara menujukan bahwa adanya peningkatan pendapatan masyarakat sekitar desa Wisa pujon kidul karena dengan adanya dicanangkannya menjadi desa wisata, terbukannya lapangan pekerjaan dan juga berkembangnya usaha baru bagi masyarakat sekitar dan juga pastinya mengurangi pengangguran yang ada pada desa wisatapujon kidul. Yang sebelumnya tidak memiliki pekerjaan tetap dengan adanya desa wisata masyarakat mempunyai pekerjaan tetap. Dan juga pendapatan yang tetap pastinya, dengan adanya pendapatan tetap dan memenuhi kebutuhan sehari-harimasyarakat.

\section{Dampak Pengembangan Desa wisata di Pujon Kidul terhadap Pendapatan Penduduk Desa Mengalami Peningkatan dari Sebelum di Canangkan sebagai Desa Wisata dan Sesudah di Canangkan Desa Wisata}

1. Terciptanya Peluang Usaha Baru

Dengan adanya desa Wisata Pujon Kidul mampu memberikan lapangan pekerjaan bagi masyarakat desa dan membuka peluang usaha baru bagi masyarakat sekitar sehingga dapat meningkatkan pendapatan masyarakat juga mengalami peningkatan karena adanya peluang usaha baru yang dapat dibuka guna memfasilitasi pengembangan desa wisata.

Peningkatan Pendapatan juga disebabkan oleh usaha-usaha yang dikelola masyarakat akibat di kembangkannya desa wisata. Contohnya melalui unit usaha BUMDES yaitu "TokoDesa" masyarakat bisa memperjual belikan hasil dari produk olahan inovatif nya sebagai oleh oleh wisatawan Desa Wisata.

Sementara itu untuk kondisi masyarakat setelah Desa di canangkan sebagai desa wisata juga ikut mengalami perubahan tersebut beberapa lebih terbukanya peluang usaha dan masyarakat lebih inovatif.

Mayoritas masyarakat merasakan adanya dampak sesudah di canangkan sebagai desa wisata, dampak yang dirasakan masyarakat salah satunya membuka lapangan pekerjaan bagi masyarakat menambah pendapatan masyarakat dan ada perubahan mata pencarian masyarakat yang membuat adanya peningkatan pendapatan.

Masyarakat Desa Wisata Pujon Kidul lebih memiliki Peluang Usaha yang Lebih Inovatif. Dengan adanya Desa Wisata Pujon Kidul ini memberikan pengaruh yang cukup signifikan terhadap kondisi penduduk Desa Pujon Kidul. Warga desa Pujon Kidul yang memiliki usaha dapat menjadikan peluang usaha lebih inovatif dan cukup menjanjikan dari sebelum dibentuknya desa wisata. 


\section{Bharanomics}

Vol. 1 No. 12020

Renaldo Silooy dkk, Dampak Pengembangan Desa Wisata

2. Sarana dan Prasarana

Desa wisata PujonKidul masih memiliki kekurangan di dalam pengembangan desa salah satu kekurangan Desa PujonKidul yaitu sarana dan prasarana: 1. Rusaknya dreinase kiri kanan poros jalan desa 2. Saluran pembuang di kiri dan kanan jalan kurang memadahi 3. Banyak kerusakan bangunan slokan 4. Sarana irigasi sebagian besar masih non teknis 5. Debit air pertanian sangat kurang di musim kemarau 6. Perlunya perawatan penyemiran jalan di desa.

Dari hasil observasi sarana dan prasarana Pujon Kidul masih memiliki kekurangan yang harus di perbaiki dan memadahi dalam pengembangan Desa wisata sarana dan prasarana sangat penting sebagai fasilitas pendukung bagi pengunjung wisata.

\section{SIMPULAN}

Berdasarkan analisa data dalam penelitian ini, maka dapat diperoleh kesimpulan tentang Dampak Pengembangan Desa Wisata Terhadap Pendapatan Masyarakat Desa Wisata Pujon Kidul, Kecamatan Pujon, Kabupaten Malang, (Jawa Timur). Setelah adanya pengembangan desa wisata di desa Pujonkidul mampu membuka lapangan pekerjaan untuk meningkatkan pendapatan melalui usaha dagang untuk memenuhi kebutuhan wisatawan dan berperan dalam menekan angka pengangguran masyarakat desa. Pengembangan desa wisata juga berdampak pada bidang pertanian dimana para petani mampu membudidayakan lahan pertanian sebagai obyek wisata sehingga menambah pendapatan petani selain dari hasil pertaniannya. Dari dikembangkannya desa Pujon Kidul sebagai desa wisata masyarakat desa lebih inovatif dalam mengelola hasil pertanian maupun peternakan menjadi olahan yang memiliki nilai ekonomi yang tinggi.

\section{DAFTAR PUSTAKA}

Kodhyat Dalam Kurniansah. (2014). Definisi Parwisata Menurut Beberapa Ahli. (http://tabeatamang.wordpress.com/2012/08/24/definisipariwisatamenurut-beberapa- ahli/).

KBBI.https://kbbi.web.id/dampak diunduh 1 Desember 2016.

Ida, B. S., \& I ,P H. (2015). Pengembangan Potensi Echo Beach Sebagai Daya Tarik Wisata Di Desa Canggu. Jurnal Destinasi Pariwisata, Vol.01.

Iskandar Wiryokusumo dalam Afrilianasari (2014). Teori Pengembangan, Surabaya Paul, A. W. \& dkk. (2018) Mikro Ekonomi. Jakarta : Erlangga. 